FACTA UNIVERSITATIS

Series: Working and Living Environmental Protection Vol. 18, № 2, 2021, pp. 79 - 85

https://doi.org/10.22190/FUWLEP2102079A

Original Scientific Paper

\title{
OXIDATIVE STRESS CAUSED BY UV RADIATION AND THE USE OF FTIR METHOD TO STUDY ITS EFFECT ON THE BIOLOGICAL TISSUES
}

\author{
UDC 616.89-008.441:543.4
}

\author{
Sofija Andjelic \\ Eye Hospital, University Medical Centre, Ljubljana, Slovenia
}

\begin{abstract}
Oxidative stress is caused by an imbalance between reactive oxygen species (ROS) generation and the capacity of antioxidant ROS scavenging systems and plays an essential role in the pathogenesis of many diseases. It is connected with cell damage, such as lipid peroxidation of membranes. One important source of oxidative stress is $U V$ radiation, which can come from the natural environment or artificial sources like welding. While sources of artificial UV radiation emit specific wavelengths depending on the application, occupational exposure to natural UV radiation has a continuous spectrum from $290 \mathrm{~nm}$ to $400 \mathrm{~nm}$. Oxidative stress can be measured by synchrotron radiation-based Fourier Transform Infrared (SR-FTIR) microspectroscopy. Oxidative effect of $U V$ can be studied on human postoperative tissue. Here we show an in vitro study of the effect of $U V C$ on the oxidative stress in human eye postoperative tissue.
\end{abstract}

Key words: oxidative stress, UV irradiation, FTIR, cataract, lens

\section{INTRODUCTION}

Oxidative stress is a phenomenon caused by an imbalance between the production and accumulation of reactive oxygen species (ROS) in cells and tissues and the ability of a biological system to detoxify these reactive products [1]. Production of ROS in healthy cells happens at a controlled rate, and the low levels of ROS are not harmful to cells. Nevertheless, under various types of environmental stress, e.g., ultraviolet (UV) radiation, ROS levels may increase dramatically and result in oxidative stress.

UV radiation is one of the main factors of ROS production triggering oxidative stress. The UV radiation in our environment is part of the electromagnetic radiation that comes from the sun. UV radiation carries higher energy $(100-400 \mathrm{~nm})$ than visible light (400-

Received September 30, 2021 / Accepted October 11, 2021

Corresponding author: Sofija Andjelic

University Eye Hospital, University Medical Centre Ljubljana, Zaloška 29a, SI-1000 Ljubljana, Slovenia

E-mail: sofija.andjelic@gmail.com

(C) 2021 by University of Niš, Serbia | Creative Commons Licence: CC BY-NC-ND 
$760 \mathrm{~nm}$ ), and stronger dose exposure to UV radiation can cause cellular damage. According to the wavelength, UV radiation is divided into: short-wave UV C (100-280 nm), mediumwave UV B $(280-315 \mathrm{~nm})$ and long-wave UV A $(315-400 \mathrm{~nm})$. The UV radiation that reaches the earth's surface is from $290-400 \mathrm{~nm}$, while the UV C is absorbed in the atmosphere before reaching it. So, although UV C, because of its high energy, represents the most biologically damaging range of UV radiation, UV $B$ and $U V C$ are the most responsible for photochemical reactions [2,3]. Even though UVC is blocked by the ozone layer, an individual can be exposed to UV C radiation upon the effect of electric arc welding with faulty shields, UV lamps without cover glasses and also from sun rays due to the depleting ozone layer. As UV C comes from artificial sources, it constitutes a potential occupational hazard [4]. Occupational exposure to sources of artificial UV radiation emits specific wavelengths depending on the application, in comparison to the natural UV radiation with a continuous spectrum from $290 \mathrm{~nm}$ to $400 \mathrm{~nm}$ at the ground level. Workers in certain occupations are exposed to significant levels of artificial UV radiation, e.g., welders, staff in television studios and on theatre stages, scientific and medical workers. Estimated number of workers exposed to artificial UV radiation in EU countries is about 1.2 million, which constitutes about $1 \%$ of total employment in the EU. The welders are the largest occupational group exposed to hazardous artificial sources of UV radiation in Europe. UV radiation levels from welding arcs are very high, and the permissible exposure duration is typically less than one minute. However, studies have shown that the UV radiation exposure of welders from welding arcs can exceed daily occupational exposure limits to the unprotected eye and skin by several thousand-fold [5, 6]. Besides workers, bystanders and passers-by are often overexposed to UV from the arcs. There are two broad categories of welding processes: gas welding and electric arc welding, where mainly arc welding produces hazardous levels of UV radiation; much more UV radiation is produced by aluminum welding than steel welding when using the same arc current [7].

Oxidative stress plays an essential role in the pathogenesis of many diseases. UV radiation is a known cause of skin cancer, skin ageing, eye damage and may affect the immune system. Regarding the eye, it ages all eye structures. Oxidative stress is involved in many eye diseases, including cataract, corneal damage, age-related macular degeneration and primary open-angle glaucoma [8], and can, in the end, lead to decreased vision. $11 \mathrm{EU}$ countries have included eye disease(s) related to occupational UV radiation exposure in their national list of occupational diseases.

Oxidative effect of UV can be studied in vitro on human postoperative tissue, like diabetic cataractous lens epithelium. Cataract is the opacity of the crystalline lens, and it accounts for $48 \%$ of world blindness. The single-layered lens epithelium underlying the anterior capsule on the anterior lens surface is built from lens epithelial cells (LECs), and it regulates the majority of the homeostatic functions of the lens. Diabetes mellitus is a chronic systemic disease that can affect all ocular structures, with cataract being the most common ocular complication. Lipid peroxidation is implicated in many human diseases, including diabetes and diabetic cataract [9].

Oxidative stress can be measured by synchrotron radiation-based Fourier Transform Infrared (SR-FTIR) microspectroscopy. FTIR is a vibrational spectroscopic technique that is a powerful tool for cell components analysis, such as lipids, proteins and nucleic acids. ROS react with lipids, proteins and nucleic acids, causing cell and tissue damage. ROS are the major initiators of lipid peroxidation. Lipid peroxidation is the oxidative 
degradation of lipids. The byproducts of lipid peroxidation cause direct damage to cell membranes. They also form protein adducts, resulting in cell and tissue damage.

\section{METHODS}

The LCs were collected from routine uneventful cataract surgery performed at the Eye Hospital, University Medical Centre, Ljubljana, Slovenia. Informed consent was provided before surgery for each patient. Tissue collection and processing were performed according to the Declaration of Helsinki. The 5-5.5 $\mathrm{mm}$ big circles of the central anterior LCs were carefully removed by continuous curvilinear capsulorhexis. The capsules were dissected so that the anterior portion of the LC (i.e., basal lamina and associated LECs) were isolated from the fiber cells that form the bulk of the lens. After collection, each LC was stored in a high-glucose medium (DMEM; Sigma, no. 5671, St. Louis, MO, USA) supplemented with $10 \%$ FBS and $1 \%$ antibiotics (penicillin- streptomycin; Sigma, no. 4333) and transported to the experimental laboratory of the Eye Hospital. Selected LC was exposed to UV irradiation (UV C lamp Sylvania G 30W, Yokohama, Japan) in a laminar hood for $60 \mathrm{~min}$ (Iskra PIO, LFV 12). The spectral irradiance of the light source $\left(\mu \mathrm{W} / \mathrm{m}^{2} / \mathrm{nm}\right)$ at the position where the tissue was measured with a radiometric measurement system consisting of a cosine corrector, a quartz fiber, and a diode-array spectrometer, calibrated with a NIST-traceable source (fiber $200 \mu \mathrm{m} / 0.22 \mathrm{NA}$, spectrometer Flame, deuterium-halogen source DH-2000, all Ocean Insight, Dunedin, FL, USA). The major peak wavelength was at $250 \mathrm{~nm}$ (UV C, 96.8\%) with $0.33444 \mathrm{~mW} / \mathrm{cm}^{2}$ the second peak wavelength was at $310 \mathrm{~nm}$ (UV B, $1.8 \%$ ) with $0.0061465 \mathrm{~mW} / \mathrm{cm}^{2}$, and the third peak wavelength was at $360 \mathrm{~nm}$ (UV A, 1.4\%) with $0.0047835 \mathrm{~mW} / \mathrm{cm}^{2}$. LCs were then prepared for FTIR studies: they were first rinsed in $5 \mathrm{~mL} \mathrm{NaCl}$ for $10 \mathrm{~min}$ and then placed by gently stretching and plating adherently on circular $13 \mathrm{~mm} \times 0.5 \mathrm{~mm}$ calcium fluoride $\left(\mathrm{CaF}_{2}\right)$ slides (Crystan Ltd., Dorset, UK) by using micro dissecting tweezers (WPI by Dumont, Med.Biologie, Germany). After this, the samples were dried under sterile conditions in the laminar flow at room temperature and stored over silica gel prior to the measurements at the ALBA synchrotron. UV C-irradiated LC was obtained from a 61-yearold female with diabetic cataract type 2 (UV). Control, non-irradiated LC was from an 82years-old female patient with a diabetic cataract (1).

\subsection{Synchrotron Radiation-Based FTIR Micro-Spectroscopy}

To assess the organic compounds' profiles, we performed measurements at the infrared micro-spectroscopy beamline MIRAS at the ALBA synchrotron light source (Barcelona, Spain) [10]. Although conventional FTIR spectroscopy is a valuable tool for examining larger cell populations in the tissues, the limited brightness of standard infrared light sources generally precludes high spatial (single-cell) resolution measurements compared to synchrotron radiation-based FTIR (SR-FTIR) microspectroscopy [11]. All SR-FTIR microspectroscopic absorption spectra were collected in transmission mode using the infrared microscope Hyperion 3000 coupled to a Vertex 70 spectrometer (Bruker, Germany), equipped with liquid nitrogen-cooled mercury cadmium telluride (MCT) detector. Each spectrum was acquired after co-adding 128 scans at a spectral resolution of $4 \mathrm{~cm}^{-1}$. We used the OPUS 8.2 (Bruker, Germany) software package for data collection. From the patient's samples of the LCs named UV and 1, we measured 170 and 200 individual areas, respectively. In 
order to achieve the single-cell data acquisition and analysis, we acquired spectra of $10 \times$ $10 \mu \mathrm{m}^{2}$ areas of the tissue by using the aperture of the microscope. The spectral analysis was focused on the wavenumber regions of lipids $\left(2,800-3,000 \mathrm{~cm}^{-1}\right)$. Spectra were baseline-corrected and unit vectornormalized in the regions of interest. Data correction and further analysis was performed by using the ORANGE software package (Bioinformatics Laboratory of the University of Ljubljana [12], (Version 3.20.1) with the spectroscopy package [13].

\section{RESULTS}

By using a novel setup at the ALBA synchrotron and the SR-FTIR microspectroscopy endstation MIRAS, we measured the complete bio-macromolecular information in UV Cirradiated and non-irradiated diabetic LCs. Here, we compared the oxidative stress parameters for UV C-irradiated diabetic type 2 LC (UV) with non-irradiated diabetic type 2 LC (1). The results are shown in Figures 1, 2 and 3.

Figure 1 shows FTIR average spectra with standard deviations obtained from the lipid region $\left(2,800-3,000 \mathrm{~cm}^{-1}\right)$. The average plot shows the most pronounced absorption bands with maxima at $2,960 \mathrm{~cm}^{-1}$, which correspond to the asymmetric vibration of $\mathrm{CH}_{3}$. The band with maxima at $2,875 \mathrm{~cm}^{-1}$ corresponds to the symmetric vibration of $\mathrm{CH}_{3}$. The main difference was in the $\mathrm{CH}_{3}$ asymmetric vibration, which was drastically decreased in the UV C-irradiated diabetic LC.

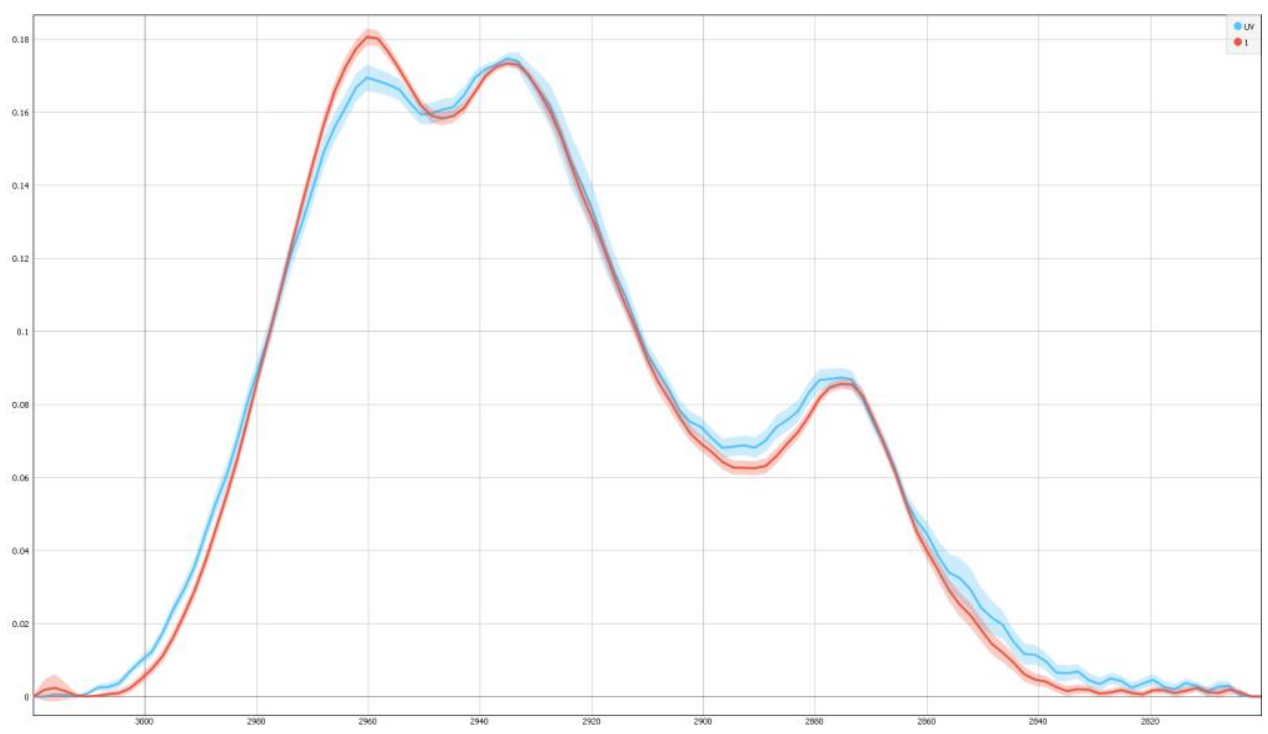

Fig. 1 Average FTIR spectra of UV C irradiated-(blue) and non-irradiated-(red) diabetic cataract LC.

In addition, the ratio of the asymmetric vibrations $\mathrm{CH}_{2}$ and $\mathrm{CH}_{3}\left(v_{\mathrm{as}} \mathrm{CH}_{2} / v_{\mathrm{as}} \mathrm{CH}_{3}\right)$, as a marker of the oxidative stress, i.e., indicators of lipids peroxidation, showed an increase in UVC irradiated diabetic LC (Fig. 2). 


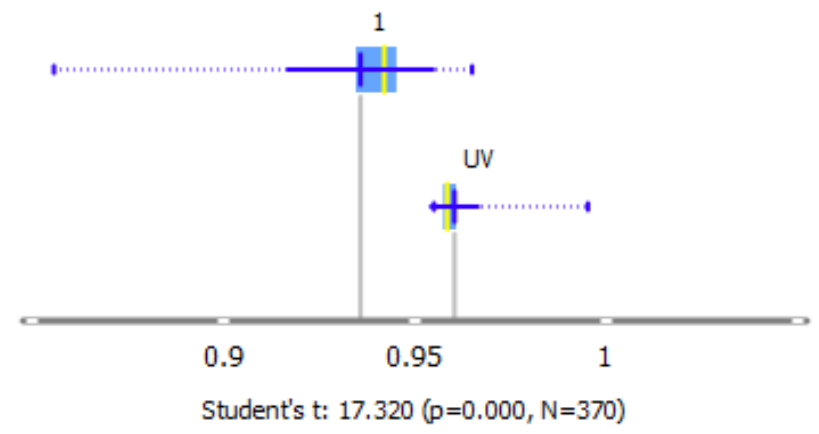

Fig. 2 Analysis of oxidative stress markers, following the lipid peroxidation using the ratio of lipidic bands: asymmetric vibrations of $\mathrm{CH}_{2}$ and $\mathrm{CH}_{3}\left(v_{\text {as }} \mathrm{CH}_{2} / v_{\text {as }} \mathrm{CH}_{3}\right)$ (A2925/A2960).

The second parameter for the oxidative stress, the ratio of the carbonyl group and asymmetric vibration of both $\mathrm{CH}_{2}$ and $\mathrm{CH}_{3}\left(v \mathrm{C}=\mathrm{O} / v_{\text {as }} \mathrm{CH}_{2}+\mathrm{CH}_{3}\right)$, showed an increase in UV irradiated diabetic LC (Fig. 3).

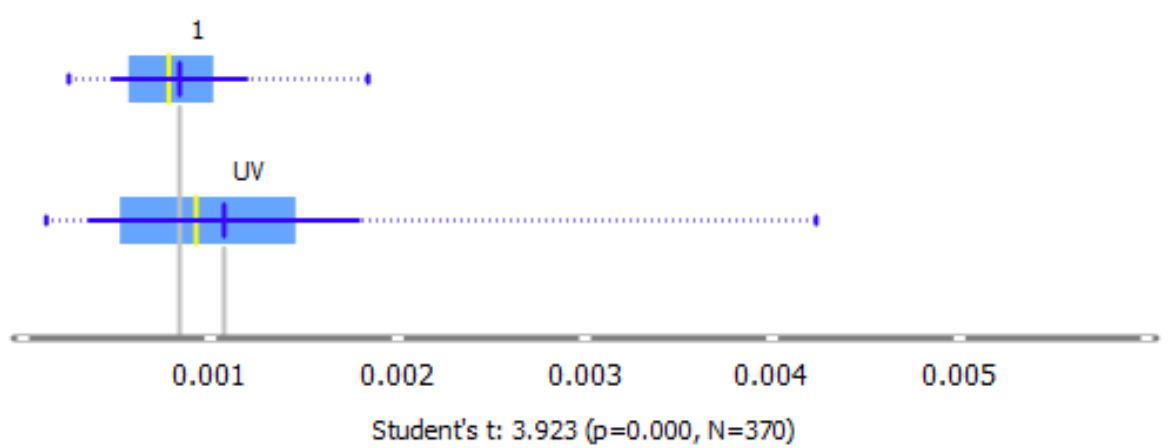

Fig. 3 Analysis of oxidative stress markers, following the lipid peroxidation by the ratio of carbonyl groups to asymmetric bands of $\mathrm{CH}_{2}$ and $\mathrm{CH}_{3}(\mathrm{~A} 1740 / \mathrm{A} 2925+2960)$.

\section{DISCUSSION}

Oxidative stress is an environmental factor influencing cataractogenesis. Understanding the changes in the human anterior LC macro-molecular composition occurring upon UV exposure is important for understanding UV-induced cataracts. Studies of cataractogenesis suggest that the light entering the eye plays an important role in acting through the photochemical generation of ROS and consequent oxidative stress to the lens cells [14]. The lens epithelial lipid peroxidation is one of the early events In UV-induced lens damage [15]. The lipid peroxidation and the breakage of lipids with the formation of reactive compounds can lead to changes in the permeability and fluidity of the membrane lipid bilayer and dramatically alter cell integrity [16]. 
In this study, we were interested in the UV C effect on lipids in LEC of LC obtained from a patient with a diabetic cataract. The induced changes after UV irradiation were compared with macromolecules in LEC of diabetic LC without UV irradiation. Here we show that in UV C-irradiated diabetic $\mathrm{LC}$, the $\mathrm{CH}_{3}$ asymmetric vibration was drastically decreased. We also show that in the UV C-irradiated diabetic LC oxidative stress markers are increased in comparison with UV C-non irradiated diabetic LC. So we found significant alterations in the level of oxidative stress after UV C irradiation. In a previous study, we found that oxidative stress was significantly higher in UV C-irradiated non-cataractous LC [17]. We also showed that $\mathrm{CH}_{3}$ asymmetric vibration was drastically decreased in the $\mathrm{UV}$ C-irradiated noncataractous LC. All suggest that UV C-irradiation induces oxidative stress both in noncataractous LCs and in diabetic cataract LCs. UVC effect on proteins and nucleic acids was not analysed in this study. As the LC LECs are important for the metabolism and the health of the hole lens, the results suggest the effect of UV C on cataract formation.

We have previously used FTIR micro-spectroscopy to study the cell compounds of LECs in human nuclear and cortical cataract types [18]. FTIR spectroscopy has also been used for the study of the whole crystalline lens [19]. Previously, we have analyzed the structural organization of the human anterior LECs by the complementary use of scanning electron microscopy, transmission electron microscopy and confocal microscopy [20].

Here we stress the usefulness of SR-FTIR microspectroscopy for studying the effect of UV radiation in correlation with occupational diseases from the postoperative tissue.

One limitation could be obtaining the postoperative tissue, another the thickness of the preparation adequate for the SR-FTIR, which should be relatively thin tissue, as the monolayer of cells is. The important limitation of this study is that the doses of UV C irradiation applied to the LC were high. The dose of irradiation would most likely damage the cornea before even reaching the lens.

However, we present proof-of-concept data in support of SR-FTIR as a tool for cell macromolecule analysis, also in the context of occupational diseases. This is especially important because artificial sources of UV radiation are used in many working environments. The established lists of occupational diseases differ between member states. In many EU countries, no diseases related to UV radiation exposure are on the list of occupational diseases. For example, $12 \mathrm{EU}$ countries have occupational disease(s) related to occupational UV radiation exposure defined on their national list of occupational diseases.

Acknowledgement: The author thanks the ALBA synchrotron light source for the beamtime allocation, experiment ID 2020024140. The author acknowledges the support from the Slovenian Research Agency (Programs P3-0333). The author thanks doc. dr Xhevat Lumi for providing the postoperative tissue and to dr. Martin Kreuzer for the measurements at ALBA.

\section{REFERENCES}

1. Pizzino, G. and others, (2017), Oxidative Stress: Harms and Benefits for Human Health, Oxid Med Cell Longev.8416763. doi:10.1155/2017/8416763

2. Wang, S.S. and Wen, W.S., (2010), Examining the influence of ultraviolet $C$ irradiation on recombinant human $\gamma$ D-crystallin, Mol. Vis., Vol. 16, pp. 2777-2790.

3. Kovécs, G., Fekete, A., Berces, A. and Ronto, G., (2007), The effect of the short wavelength ultraviolet radiation. An extension of biological dosimetry to the UV-C range, J. Photochem. Photobiol. B., Vol. 88, pp. $77-82$. 
4. Tenkate, T.D., (1999) Occupational Exposure to Ultraviolet Radiation: A Health Risk Assessment, Rev. Environ. Health, Vol. 14, pp. 187-209.

5. Sliney, D.H. and Wolbarsht, M.L., (1980), Safety with lasers and other optical sources. New York: New York: Plenum Publishing Corp.

6. Sliney, D.H. and Matthes, R. (eds.), (1998), The Measurement of Optical Radiation Hazards, ICNIRP Publication 6/98; CIE Publication CIE-x016-1998 (ICNIRP: Munich and CIE: Vienna); 1999.

7. Hietanen, M. and von Nandelstadh, P.: Measurements of optical radiation emitted by welding arcs, In: Measurements of optical radiation hazards, ICNIRP 6/98 and CIE x016-1998, pp. 553-557.

8. Kruk, J., Kubasik-Kladna, K. and Aboul-Enein, H.Y., (2015), The Role Oxidative Stress in the Pathogenesis of Eye Diseases: Current Status and a Dual Role of Physical Activity, Mini Rev Med Chem., Vol. 16(3), pp. 241-257. doi: 10.2174/1389557516666151120114605. PMID: 26586128.

9. Simonelli, F., Nesti, A., Pensa. M., Romano, L., Savastano, S., Rinaldi, E. and Auricchio G., (1989), Lipid peroxidation and human cataractogenesis in diabetes and severe myopia, Exp Eye Res., Vol. 49(2), pp. 181-187. doi: 10.1016/0014-4835(89)90088-2. PMID: 2767166.

10. Yousef, I. and others, (2017), MIRAS: The Infrared Synchrotron Radiation Beamline at ALBA, Synchrotron Radiat. News, Vol. 30, pp. 4-6.

11. Miller, L.M. and Dumas, P., (2006), Chemical imaging of biological tissue with synchrotron infrared light, Biochim. Biophys. Acta Biomembr., Vol. 1758, pp. 846-857.

12. Demsar, J. and others, (2013), Orange: Data Mining Toolbox in Python, J. Mach. Learn. Res., Vol. 14, pp. 2349-2353.

13. Toplak, M. and others, (2017), Infrared Orange: Connecting Hyperspectral Data with Machine Learning, Synchrotron Radiat. News, Vol. 30, pp. 40-45.

14. Varma, S.D., Kovtun, S. and Hegde, K.R. (2011), Role of ultraviolet irradiation and oxidative stress in cataract formation-medical prevention by nutritional antioxidants and metabolic agonists, Eye Contact Lens, Vol. 37, pp. 233-245.

15. Hightower, K.R., Mccready, J.P. and Borchman, D., (1994), Membrane damage in UV-irradiated lenses, Photochem. Photobiol.,

16. Dix, T.A. and Aikens, J., (1993), Mechanisms and biological relevance of lipid peroxidation initiation, Chemical Research in Toxicology., Vol. 6(1), pp. 2-18.

17. Lumi, X., Dučić, T., Kreuzer, M., Hawlina, M. and Andjelic, S., (2021), UV Effect on Human Anterior Lens Capsule Macro-Molecular Composition Studied by Synchrotron-Based FTIR Micro-Spectroscopy, Int. J. Mol. Sci., Vol. 22(10), pp. 5249.

18. Kreuzer, M., Dučič, T., Hawlina, M. and Andjelic, S., (2020), Synchrotron based FTIR microspectroscopy of protein aggregation and lipids peroxidation changes in human cataractous lens epithelial cells, Sci. Rep., Vol. 10, pp. 15489.

19. Paluszkiewicz, C. and others, (2018), Vibrational microspectroscopy analysis of human lenses, Spectrochim. Acta A Mol. Biomol. Spectrosc., Vol. 188, pp. 332-337.

20. Andjelic, S., Drašlar, K., Hvala, A., Lopic, N., Strancar, J. and Hawlina, M., (2016), Anterior lens epithelial cells attachment to the basal lamina, Acta Ophthalmol.: Vol. 94, e183-e188.

\section{OKSIDATIVNI STRES UZROKOVAN UV ZRAČENJEM I UPOTREBA FTIR METODE ZA PROUČAVANJE NJEGOVOG UČINKA NA BIOLOŠKA TKIVA}

Oksidativni stres uzrokovan je neravnotežom između stvaranja reaktivnih vrsta kiseonika (ROS) i kapaciteta antioksidativnih sistema za uklanjanje ROS i igra bitnu ulogu u patogenezi mnogih bolesti. Povezan je sa oštećenjem ćelija, poput peroksidacije membrana lipidima. Jedan važan izvor oksidativnog stresa je UV zračenje koje može doći iz prirodnog okruženja ili iz veštačkih izvora poput zavarivanja. Dok izvori veštačkog UV zračenja emituju određene talasne dužine u zavisnosti od primene, profesionalna izloženost prirodnom UV zračenju ima kontinuirani spektar od $290 \mathrm{~nm}$ do $400 \mathrm{~nm}$. Oksidacioni stres se može meriti infracrvenom mikrospektroskopijom zasnovanom na sinhrotronskom zračenju Fourier-ove transformacije (SR-FTIR). Oksidativni efekat UV zračenja može se proučavati na postoperativnom tkivu čoveka. Ovde prikazujemo in vitro studiju uticaja UV C na oksidativni stres u postoperativnom tkivu ljudskog oka.

Ključne reči: Oksidativni stres, UV zračenje, FTIR, katarakta, sočiva 